Document downloaded from:

http://hdl.handle.net/10251/105353

This paper must be cited as:

Balaguer-Arnandis, E.; Cuartas Uribe, BE.; Bes-Piá, M.; Mendoza Roca, JA.; Galiana Aleixandre, MV. (2017). Performance Improvement of a Sequencing Batch Reactor for Treating Tannery

Wastewaters. Chemical Engineering \& Technology. 40(9):1666-1673. doi:10.1002/ceat.201600410

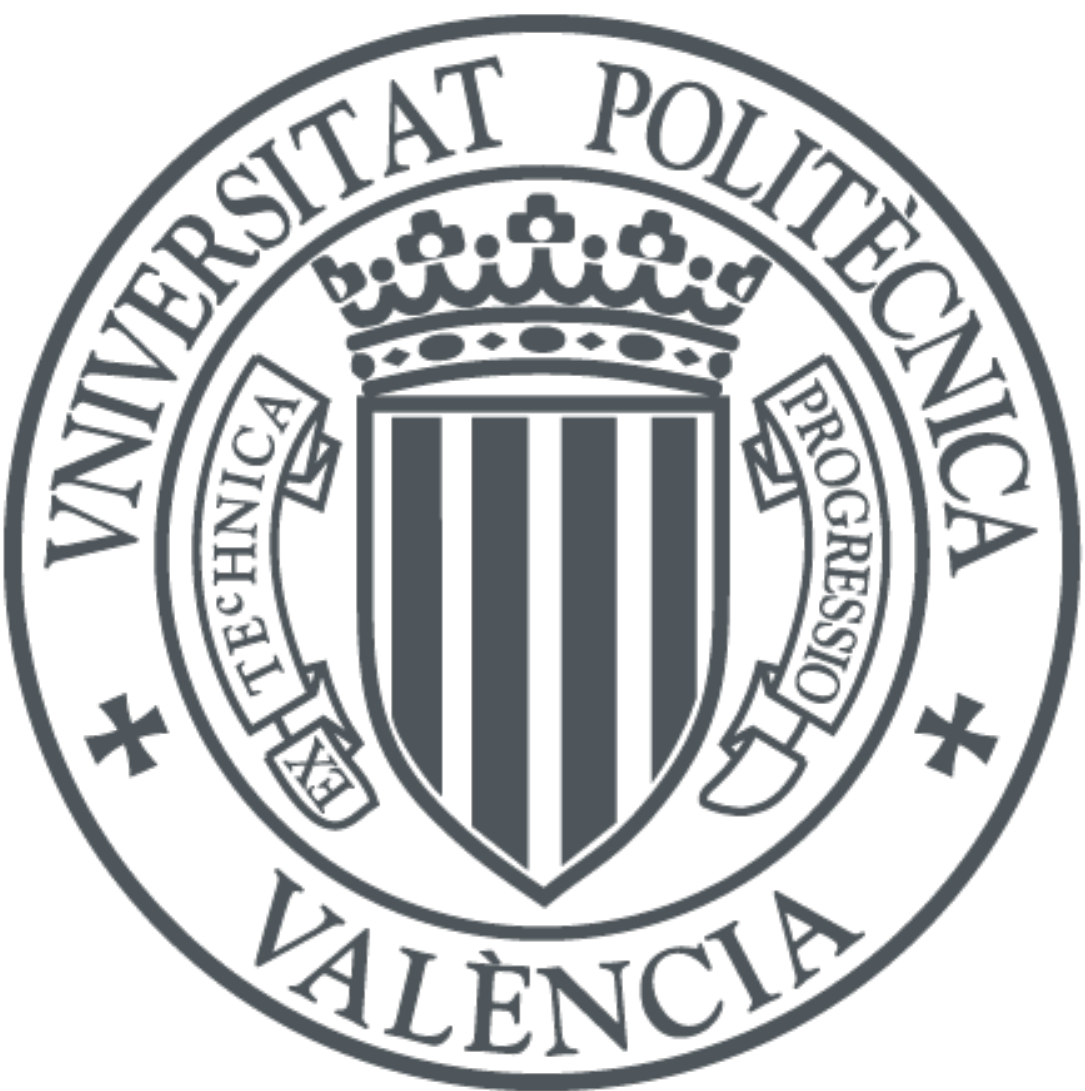

The final publication is available at

http://doi.org/10.1002/ceat.201600410

Copyright John Wiley \& Sons

Additional Information 


\section{Performance Improvement of a Sequencing Batch Reactor Treating Tannery Wastewaters}

Esther Balaguer-Arnandis ${ }^{1}$, Beatriz Cuartas-Uribe ${ }^{1 *}$, M. Amparo Bes-Piá ${ }^{1}$, Jose Antonio Mendoza-Roca ${ }^{1}$, M. Vicenta Galiana-Aleixandre ${ }^{1}$

${ }^{1}$ Instituto de Seguridad Industrial, Radiofísica y Medioambiental, Universitat Politècnica de València, Camino de Vera, s/n, Valencia 46022, Spain

*Correspondence: B. Cuartas-Uribe (E-mail: beacuau1@iqn.upv.es), Instituto de Seguridad Industrial, Radiofísica y Medioambiental, Universitat Politècnica de València, Camino de Vera, s/n, Valencia 46022, Spain

\section{Abstract}

Minimizing the hydraulic retention time (HRT) of a sequencing batch reactor (SBR) treating tannery wastewater it is an important goal. Different HRTs were tested and the best value was chosen according to the soluble COD removal efficiencies. After that, a series of experiments was carried out with two cationic polyelectrolytes added to the system in two different modes in order to improve the quality of the effluent. Both modes were evaluated in terms of soluble COD, suspended solids concentration and turbidity in the final effluent. Results show that the reduction of the HRT to 2 days did not diminish the COD removal efficiencies (values around $90 \%)$. After adding $4 \mathrm{mg} \mathrm{L}^{-1}$ of $\mathrm{CH}-30$ polyelectrolyte in the SBR effluent, the turbidity and the total suspended solids concentration in the final effluent were reduced to values lower than $10 \mathrm{NTU}$ and $100 \mathrm{mg} \mathrm{L}^{-1}$, respectively.

Keywords: SBR, Tannery wastewater, Sludge settleability, Polyelectrolytes

\section{Introduction}

Wastewater from tanneries processing raw hides is characterized by high organic matter concentration and salinity (sulphates, chlorides and trivalent chromium). Usually between $24-37 \mathrm{~m}^{3}$ of water per tonne of processed leather is required in the process, having a great environmental impact. As a consequence of productive cycle, the conductivity in the global wastewater can vary between 8 and $12 \mathrm{mS} \mathrm{cm}^{-1}$, meanwhile $\mathrm{pH}$ values range between 8 and 10 and soluble chemical oxygen demand (COD) values are between $1500-4000 \mathrm{mg} \mathrm{L}^{-1}$.

The use of a wide range of chemicals in the tannery processes contributes to a low biodegradability of their wastewater. Thus, the conventional biological treatments are frequently inadequate due to the complexity of chemicals used in the process. This is the reason why alternative or complementary treatments to biological processes like advanced oxidation processes $[1,2]$ or membrane techniques $[3,4]$ have been reported in the literature.

Among the biological treatments, SBR could be a suitable option to treat this type of wastewaters. SBR is a process widely studied for high polluted wastewaters. The difference with a conventional

Received: July 25, 2016; revised: March 02, 2017; accepted: May 11, 2017

This article has been accepted for publication and undergone full peer review but has not been through the copyediting, typesetting, pagination and proofreading process, which may lead to differences between this version and the final Version of Record (VOR). This work is currently citable by using the Digital Object Identifier (DOI) given below. The final VoR will be published online in Early View as soon as possible and may be different to this Accepted Article as a result of editing. Readers should obtain the final VoR from the journal website shown below when it is published to ensure accuracy of information. The authors are responsible for the content of this Accepted Article.

To be cited as: Chem. Eng. Technol. 10.1002/ceat.201600410

Link to final VoR: https://doi.org/10.1002/ceat.201600410

This article is protected by copyright. All rights reserved. 
activated sludge (CAS) process lies on the operation in cycles, which consist of a series of phases, including reaction and sedimentation $[5,6]$. It has been reported that the selection of microorganisms that are able to degrade synthetic and slowly biodegradable compounds is enhanced by the dynamic conditions that are typical of periodic systems like SBRs. In the literature, studies of degradation of different industrial wastewaters (for example from textile and from chemical and petrochemical industries) by means of SBR technology have been reported [7-9].

The main problems of the biological treatment of tannery wastewaters are the non-biodegradable fraction of the organic matter (this implies a refractory COD in the process effluent), the high hydraulic retention times (HRT) required for the treatment and poor sludge settleability due to high and oscillating salinities. Concerning wastewater COD, Karahan et al. [10] identified through particle size distribution and oxygen uptake rate analysis a very slowly biodegradable fraction that exerted an inhibitory effect on the biomass, which is related with the required high HRTs. Di laconi et al. [11] reported an increase (from 90 to $96 \%$ ) in the COD removal efficiency in a biological treatment of tannery wastewaters by previous ozonation, what achieved the break of large non-degradable molecules into more simple organic molecules that could be degraded in the biological stage.

Regarding to sedimentation problems, it has to be commented that high and variable salinity causes the improper formation of activated sludge aggregates [12]. Thus, high salinity can lead to the deterioration of effluent quality (high turbidity) and, as a consequence, sludge washout [13]. In order to avoid problems related to sedimentation, some authors [14] have proposed to use membrane bioreactors for tannery wastewaters, but the high operating costs of this process and the membrane fouling caused by the non-degradable COD and by scaling have stopped its application. Thus, the addition of polyelectrolyte either to the reactor before the sedimentation phase or to the treated effluent in a separated tank could be a feasible alternative.

On the other hand, polyelectrolytes are widely used for physical-chemical treatment and sludge dewatering. Prior to its use, laboratory tests have to be carried out to optimize the process. Previous works have investigated the settleability process by studying the flocs structure and the sludge-water separation. The density and diameter of flocs are known to affect the settling behaviours [15]. However, the flocs size is relatively more significant in determining settling rate.

Its application to industrial wastewaters has a great future as they usually do not have to treat very high wastewater volumes (which could be a limitation and would drive to install several reactors in parallel) [16]. Industrial effluents are characterized by high salt concentrations and presence of low biodegradable substances, which create problems like loss of settleability and poor final effluent quality in the conventional activated sludge reactors. However, these problems could be diminished when a SBR process is used [17].

In this paper the biological treatment by SBR of tannery wastewaters has been studied. Firstly, the SBR was started-up and afterwards the work was focused on the solution of the two main problems of the process: the excessive HRT and the problems occurred in biomass sedimentation. Although there are papers in the literature dealing with biological tannery wastewater treatment, only a few papers emphasize these items, whose solution is required so that full-scale plants could be feasible. Thus, testing of different HRTs could contribute to maintain an effective reduction of soluble COD, suspended solids and turbidity in the effluent.

\section{Materials and methods}

\subsection{Sequencing batch reactor}

Experiments were carried out in a laboratory SBR plant (Fig. 1). It consists in a polyethylene tank of 11 litres of capacity. The reactor diameter is $21.5 \mathrm{~cm}$ and its height is $30 \mathrm{~cm}$. with a total working volume $V_{\text {reaction }}$ ) of $6 \mathrm{~L}$. There are two automatic valves at the top of the tank, one that opens for the 
feeding phase and the other that opens for draining the supernatant (after the settling phase). Filling and draining were carried out with peristaltic pumps ( $D-25 \mathrm{~V}$ from Dinko). A manual valve, located at the bottom, was opened for withdrawing the excess of the sludge produced in the SBR.

Homogeneous mixing in the reactor was provided by a Heidolph mechanical stirrer and the air was supplied by means of a compressor connected to a diffuser located at the bottom of the reactor. The compressor ensures an oxygen concentration in the system between 2-3 $\mathrm{mg} \mathrm{L}^{-1}$. The different operation phases were controlled by timers.

\section{(Figure 1)}

\subsection{Tannery wastewater samples}

Wastewater samples were supplied from a tannery industry located in Valencia. The samples were taken from the effluent of the physical-chemical treatment carried out in the industry. Due to the variable salinity, this effluent was previously diluted when conductivity was higher than $9 \mathrm{mS} \mathrm{cm}^{-1}$. In this way, settling problems would not be associated to the salinity variation. This can be avoided at an industrial scale by an equalizer tank.

The average chemical composition of the diluted tannery wastewater is shown in Tab.1. Total and suspended solids were measured according to Standard Methods [18]. Phosphorous and soluble COD were determined using cell tests from Spectroquant NOVA 60 de Merck. Conductivity and pH were measured with a conductimeter (model 542) and a pH-Meter (GLP-22) from CRISON, respectively.

(Table 1)

\subsection{Experiments and measurements}

\subsubsection{SBR experiments}

The inoculum (mixed liquor) for the SBR laboratory plant was taken from the biological reactor of a domestic wastewater treatment plant.

In the acclimatization stage, the SBR was fed with increasing wastewater volume as biomass degraded the influent COD. In addition, the MLSS was monitored in order to check the biomass growth after the initial depletion. Total and volatile suspended solids of the mixed liquor were determined according to Standard Methods [18].

After the acclimatization stage, SBR experiments were performed varying the hydraulic retention time (HRT). The cycle duration and the phases per cycle were the same as in the SBR start-up.

Tab. 2 shows operating parameters for each HRT tested. $t_{F}$ is the feeding time, $t_{R}$ is the aerobic reaction time, $t_{S}$ is the settling time, $t_{D}$ is the draw time and $t_{l}$ is the idle time, taking into account that the whole duration of each cycle was $12 \mathrm{~h}\left(t_{c}\right)$. This table also includes the replacement volume per cycle, the fill time ratio (FTR) and the volume exchange ratio (VER). The fill time ratio is the proportion between $t_{F}$ and $t_{c}$. The volume exchange ratio is the quotient between the feed volume $\left(\mathrm{V}_{\mathrm{F}}\right)$ and the reaction volume $\left(\mathrm{V}_{\text {reaction }}\right)$.

(Table 2).

This article is protected by copyright. All rights reserved. 


\subsubsection{Settling experiments}

In order to improve the process performance, two cationic polyelectrolytes were tested to improve the efficiency of the mixed liquor settling. The polyelectrolytes, both provided by Chemipol S.A. (Spain) were $\mathrm{CH}-30$ and $\mathrm{CV}-250$. Their properties are listed in Tab. 3.

(Table 3).

The settling experiments were carried out in two operating modes in the test with the selected HRT (test referred as T4, HRT=48h).

In the first operation mode (Mode 1), each polyelectrolyte was added to the SBR effluent (samples of $250 \mathrm{~mL}$ ) in a conventional jar-stirring device. Polyelectrolytes doses of 1, 2, 3, 4 and $5 \mathrm{mg} \mathrm{L}^{-1}$ were added and mixed at $30 \mathrm{rpm}$ for 15 minutes. After that, the samples were poured in Imhoff cones and settled during 30 minutes $\left(V_{30}\right.$ was measured).

In the second operating mode (Mode 2), the $\mathrm{CH}-30$ polyelectrolyte was added in the SBR reactor in different concentrations (1-5 $\mathrm{mg} \mathrm{L}^{-1}$ ) before the sedimentation phase. The stirring velocity and the mixing time were identical to that of the Mode 1, i.e. $30 \mathrm{rpm}$ and 15 minutes.

For both modes, the total settled sludge volume $\left(V_{30}\right)$, turbidity and suspended solid concentration were measured.

\section{Results and discussion}

\subsection{SBR experiments}

According to the start-up strategy, during acclimatization stage the soluble COD removal efficiency was kept almost constant since the fed wastewater volume was gradually increased, reaching values higher than the established threshold (around 90\%, Fig. 2).

(Figure 2)

However, MLSS went down at the beginning of the starting up since biomass was still not completely adapted to the wastewater. After five days, a gradual increase of MLSS was observed. Thus, biomass yield increased sharper after the $15^{\text {th }}$ day. The high biomass yield and the constant soluble COD removal efficiency led to confirm that biomass acclimation had finished. Concerning MLVSS concentration, it has to be highlighted that, on average, $64 \%$ of the MLSS were volatile. This low percentage was due to low organic load values (between 0.032 and $0.080 \mathrm{gBOD}_{5} /(\mathrm{gMLSS} \cdot \mathrm{d})$ ), which are in concordance with the high HRT.

\subsection{Effect of the variation of the HRT on the SBR performance}

As commented in materials and method section, the raw wastewater was diluted with the aim of operating the SBR without sudden changes in salinity, since previous studies $[19,20]$ reported that salinity changes affect negatively the biological process efficiency [21, 22]. In addition, dilution provides less polluting load, what improves the removal efficiencies when toxic substances are also found, like in tannery wastewater, as reported by Sirianuntapiboon [23].

Fig. 3 shows the evolution of the soluble COD removal efficiency and MLSS and MLVSS concentrations in the SBR during the tests. It is observed that, for all tests COD removal efficiency was reduced down to $80 \%$ after two days of operation. This can be probably due to the inhibition 
effect of synthetic organic substances in wastewater that accumulate in the reactor, as reported by Karahan et al. [10]. Thus, COD removal efficiencies reached in the start-up phase could not be achieved. Concerning the variation of the COD with the HRT, it can be observed that when the HRT values were reduced, COD removal efficiency kept approximately constant (between 85 and 95\%). Consequently, the variation of the HRT did not influence the reactor performance. This behaviour was based on maintaining a high MLSS concentration in the reactor. It has to be mentioned that the diminution of the HRT implied an increase in the organic fraction of the MLSS; thereby more microorganisms were available to degrade the wastewater COD. This increase was particularly important at HRTs of $57.6 \mathrm{~h}$ and $48 \mathrm{~h}$. The \%MLVSS achieved were $60 \%, 70 \%, 82 \%$ and $85 \%$, for HRTs of $144 \mathrm{~h}, 71 \mathrm{~h}, 57.6 \mathrm{~h}$ and $48 \mathrm{~h}$, respectively. It was a consequence of the diminution in the endogenous respiration of the microorganisms, since more substrate is available (the diminution of the HRT implied an increase of the organic load) [23].

(Figure 3)

It is worth commenting that a residual soluble COD between $400-600 \mathrm{mg} \cdot \mathrm{L}^{-1}$ remained in the effluent of the SBR. This organic matter is referred to be the refractory matter; i.e. the matter that cannot be degraded by the microorganisms. In this way, these compounds, which come from some chemical products used in the tannery, were eliminated neither in the previous physical-chemical treatment nor in the biological treatment.

\subsection{Settling experiments}

Although the best results in terms of soluble COD removal efficiencies were achieved at HRT=2 days, high turbidity values in the effluent were measured (165 NTU). These results could be caused by the presence of filamentous bacteria that affects negatively to the flocs structure (Fig. 4a) [21, 22].

Fig.s $4 \mathrm{~b}$ and $4 \mathrm{c}$ show some of the microorganisms in the mixed liquor from test $\mathrm{T4}$. The microorganism found like amoeboid, flagellates, ciliates and rotifers as well as the floc structure were indicators of the good efficiency of the biological treatment.

(Figure 4)

In order to improve the quality of the effluent additional settling experiments were carried out using polyelectrolytes. [27, 24].

\subsubsection{Polyelectrolyte selection for settling experiments.}

Since SBR effluent and the mixed liquor have negative charge due to the ionization of functional groups such as carboxylic, sulphate and phosphate of the extracellular polymeric substances, two cationic polyelectrolytes were chosen.

Figs. 5 and 6 depict the effect of two cationic polyelectrolytes (CV-250 and $\mathrm{CH}-30$ ) on the turbidity and TSS. Turbidity and TSS were measured in the supernatant after the tests carried out in mode 1.

(Figure 5)

(Figure 6)

This article is protected by copyright. All rights reserved. 
The use of both polyelectrolytes reduced significantly the suspended solids and the turbidity. As expected, both parameters followed the same tendency. At low concentrations, the values of these parameters were similar for both polyelectrolytes whereas differences were observed at the highest concentrations.

The lowest value of turbidity was obtained with $\mathrm{CH}-30$ at a concentration of $4 \mathrm{mg} \mathrm{L}^{-1}$ with a turbidity removal of $95 \%$ whereas with CV-250 the removal efficiency was $81 \%$ with $1 \mathrm{mg} \mathrm{L}^{-1}$. Besides, the highest TSS removal efficiencies were $79 \%\left(4 \mathrm{mg} \mathrm{L}^{-1}\right)$ and $66 \%\left(1 \mathrm{mg} \mathrm{L}^{-1}\right)$ for $\mathrm{CH}-30$ and $\mathrm{CV}-250$, respectively. For both polyelectrolytes the soluble COD removal values barely changed between 21$24 \%$.

Fig. 7 depicts the influence of the polyelectrolytes concentration on the settled sludge volume $\left(V_{30}\right)$. For $\mathrm{CH}-30$ the increase of the polyelectrolyte concentration did not change appreciably the settled sludge volume. On the contrary, solids sedimentation was not observed for CV-250, except for $1 \mathrm{mg}$ $\mathrm{L}^{-1}$. These results are in accordance with the measured turbidity and suspended solids in the supernatants. Thus, for CV-250, the slight removal efficiencies achieved for turbidity and TSS were the expected ones after having observed a low settled sludge volume.

(Figure 7)

In general, it was observed that when cationic polyelectrolytes were added to the SBR effluent (mode 1), compact flocs were formed due to the electrostatic attraction between cationic polyelectrolyte and the colloid particles. However, the size of the formed flocs was different depending on the kind and dose of added polyelectrolytes. Since CV-250 has higher molecular weight than $\mathrm{CH}-30$, bigger flocs were formed when $\mathrm{CV}-250$ was tested. But, on the contrary, the flocs consistency was better for $\mathrm{CH}-30$. $\mathrm{CH}-30$ would be within a micro-polyelectrolyte network where flocs are more resistant and denser comparing to CV-250 that could not be completely enmeshed in the network, due to the electrostatic repulsion and steric hindrance.

Taking into account these results, the $\mathrm{CH}-30$ was chosen for the second part of the settling experiments (adding the polyelectrolyte in the SBR following mode 2).

\subsubsection{Comparison between operating mode 1 (polyelectrolyte addition to the SBR effluent) and operating mode 2 (polyelectrolyte addition to the SBR reactor) using $\mathrm{CH}-30$.}

Fig. 8 shows the turbidity and TSS values when $\mathrm{CH}-30$ was added to the effluent (mode 1 ) and into the reactor (mode 2 ) in order to compare both operating modes.

\section{(Figure 8)}

According to the results shown in these figures, the best results were obtained when the polyelectrolyte was added to the SBR effluent. In fact, it can be highlighted that the additions of polyelectrolyte in mode 2 worsen the effluent quality increasing the turbidity values. In mode 1 , the turbidity values were lower than 10 NTU achieving the lower value at $4 \mathrm{mg} \mathrm{L}^{-1}$. The TSS values were slightly influenced for a polyelectrolyte concentration higher than $1 \mathrm{mg} \mathrm{L}^{-1}$.

The results obtained in both operating modes can be discussed from different points of view. On one hand, these results could be attributed to the adsorption of the polyelectrolyte on colloid particles through mainly the hydrophobic, hydrogen bonding and the Van der Waals effects. However, as figure 8 shows, these effects were different according to the operating mode. 
For mode 1, the electrostatic attraction between cationic polyelectrolyte and the colloid particles generated more compact flocs as well as a better capture efficiency of small and dispersed particles. This is in accordance with lower turbidity values in supernatant after 30 minutes of settling. In mode 2 poorer flocculating properties were achieved. Thus, to improve the settling experiments in mode 2 , the polyelectrolyte concentration should be increased $[25,26]$.

On the other hand, these results could be attributed to the toxicity effect of the polyelectrolyte on the biological process as some authors reported [27], driving to bacterial damage or preventing bacterial adhesion mechanisms within the flocs. Thus, polyelectrolyte might reduce the overall bonding capacity in the flocs through changes in extracellular polymeric substances. As a consequence, the polyelectrolyte works better in mode 1 instead of mode 2 due to the interactions between polyelectrolyte and colloids. Polyelectrolyte has more chance to bridge with particles found in the effluent than in the mixed liquor of the SBR reactor [28].

\section{Conclusions}

The reduction of the HRT from $144 \mathrm{~h}$ to $48 \mathrm{~h}$ in an SBR treating tannery wastewater was possible without diminishing the soluble COD removal efficiencies. It was proved that efficiencies between 75 and $85 \%$ were achieved. These values are limited by the refractory COD of the tannery wastewater. However, for all the tested HRTs, settleability problems appeared and high turbidity values were measured.

$\mathrm{CH}-30$ polyelectrolyte was more effective than CV-250 in terms of turbidity and TSS removals in the effluent achieving efficiencies of $95 \%$ and $79 \%$, respectively at $\quad 4 \mathrm{mg} \cdot \mathrm{L}^{-1}$. As a result, the settling sludge volume for $\mathrm{CH}-30$ was higher than $\mathrm{CV}-250$. The formed flocs with $\mathrm{CH}-30$ were smaller but more consistent than CV-250.

Two ways of adding the $\mathrm{CH}-30$ polyelectrolyte were tested. The best results were obtained when the polyelectrolyte was added to the effluent of the SBR. The lower colloidal particles content related to the mixed liquor improved the bonds between colloidal particles and the polyelectrolyte.

\section{Symbols used}

\begin{tabular}{|c|c|c|}
\hline COD & \multicolumn{2}{|c|}{$\left[\mathrm{mg} \mathrm{L}^{-1}\right]$ chemical oxygen demand } \\
\hline$t_{c}$ & {$[\mathrm{~h}]$} & cycle time \\
\hline CAS & {$[-]$} & conventional activated sludge \\
\hline$t_{D}$ & [minutes] & draw time \\
\hline$V_{F}$ & {$[\mathrm{~L}]$} & Feed volume \\
\hline$t_{F}$ & [minutes] & feeding time \\
\hline FTR & {$[\mathrm{h}]$} & fill time ratio \\
\hline HRT & {$[\mathrm{h}]$} & hydraulic retention time \\
\hline$t_{1}$ & [minutes] & idle time \\
\hline MLSS & \multicolumn{2}{|c|}{$\left[\mathrm{mg} \mathrm{L}^{-1}\right]$ mixed liquor suspended solids } \\
\hline \multicolumn{3}{|c|}{ MLVSS [mg L $\mathrm{L}^{-1}$ ] mixed liquor volatile suspended solids } \\
\hline $\mathrm{CH}-30$ & {$[-]$} & polyelectrolyte \\
\hline CV-250 [-] & \multicolumn{2}{|c|}{ polyelectrolyte } \\
\hline$t_{R}$ & [minutes] & reaction time \\
\hline
\end{tabular}




$\begin{array}{lll}\mathrm{V}_{\text {reaction }} & {[\mathrm{L}]} & \text { reaction volume } \\ \text { SBR } & {[-]} & \text { sequencing batch reactor } \\ \mathrm{V}_{30} & {\left[\mathrm{~mL} \mathrm{~L}^{-1}\right] \text { settled sludge }} \\ t_{s} & {[\text { minutes }]} & \text { settling time } \\ \text { TSS } & {\left[\mathrm{mg} \mathrm{L}^{-1}\right] \text { total suspended solids }} \\ V_{\text {total }} & {[\mathrm{L}]} & \text { total volume } \\ \text { VER } & {[\mathrm{h}]} & \text { volume exchange ratio }\end{array}$

\section{Acknowledgements}

This work was supported by the Universitat Politècnica de València (project ref: PAID-06-10-2269). 


\section{References}

[1] C. Di laconi, R. Ramadori, A. Lopez, Bioresour. Technol. 2009, 100:6121-6124. DOI:10.1016/j.biortech.2009.06.022.

[2] S. Sundarapandiyan, R. Chandrasekar, B. Ramanaiah, S. Krishnan, P. Saravanan, J. Hazard. Mater. 2010, 180:197-203. DOI:10.1016/j.jhazmat.2010.04.013.

[3] J. Dasgupta, D. Mondal, S. Chakraborty, J. Sikder, S. Curcio, H.A. Arafat, Ecotox. Environ. Safe. 2015, 121:22-30. DOI:10.1016/j.ecoenv.2015.07.006

[4] A. Deghles, U. Kurt, Chem. Eng. Process. 2016, 104:43-50. DOI:10.1016/j.cep.2016.02.009.

[5] P.A. Wilderer, R.L. Irvine, M.C. Goronszy, Sequencing Batch Reactor Technology, First Edition, IWA Publishing, London 2001.

[6] N. Artan, D. Orhon, Mechanism and design of sequencing batch reactors for nutrient removal, First Edition, IWA Publishing, London 2005.

[7] A. Vargas, G. Soto, J. Moreno, G. Buitrón, Water Sci. Technol. 2000, 42 (5-6), 163-170.

[8] A. Chiavola, R.L. Baciocchi, R. Gavasci, P. Sirini, Water Sci. Technol. 2004, 50 (10), 235-242.

[9] E. Zuriaga-Agustí, G. Garrido-Mauri, J.A. Mendoza-Roca, A. Bes-Piá, J.L. Alonso-Molina, Chem. Eng. J. 2012, 209, 318-324. DOI:10.1016/j.cej.2012.08.004

[10] O. Karahan, S. Dogruel, E. Dulekgurgen, D. Orhon. Water Res. 2008, 42, 1083-1092.

DOI:10.1016/j.watres.2007.10.001.

[11] C. Di laconi, A. Lopez, R. Ramadori, A.C. Di Pinto, R. Passino, Water Res. 2002, 36: 2205-2214. DOI: 10.1016/S0043-1354(01)00445-6.

[12] D.P. Mesquita, O. Dias, A.M.A. Dias, A.L. Amaral, E.C. Ferreira, Analytica Chimica Acta 2009, 642:94-101.

[13] J. Guo, S. Wang, Z. Wang, Y. Peng, J. of Water Process Eng. 2014, 1:108-114.

DOI:10.1016/j.jwpe.2014.03.011.

[14] Z. Huang, S.L. Ong, H.Y. Ng, Water Res. 2011, doi:10.1016/j.watres.2010.08.035

[15] G.W. Chen, I.L. Chang, W.T. Hung, D.J. Lee, Water Res. 30:1844-1850. DOI:10.1016/00431354(95)00322-3

[16] I.J. Kang, C.H. Lee, K.J. Kim, Water Res. 2003, 37:1192-1197. DOI: 10.1016/S0043-1354 (02) 00534-1.

[17] E.U. Cokgor, O. Karahan, D. Orhon, J. Hazard. Mater. 2008, 156:292-299. DOI: 10.1016/j.jhazmat.2007.12.037

[18] APHA, AWWA. Standard Methods for the Examination of Water and Wastewater, 21th Edition, American Public Health Association, American Water Works Association, Washington DC 2005.

[19] M.V. Galiana Aleixandre, Degree Thesis, Universitat Politécnica de Valencia (Spain) 2010.

[20] A. Uygur, F. Kargı, Enzyme and microb. Tech. 2003, 34:313-318. DOI:

10.1016/j.enzmictec.2003.11.010.

[21] T. Panswad, C. Anan, Water Res. 1999, 33 (5):1165-1172. DOI:10.1016/S0043-1354(98)00314-5.

[22] M.S. Moussa, D.U. Sumanasekera, S.H. Ibrahim, H.J. Lubberding, C.M. Hooijmans, H.J. Gijzen, M.C.M. van Loosdrecht, Water Res. 2006, 40(7):1377-1388. DOI: 10.1016/j.watres.2006.01.029. 
[23] S. Sirianuntapiboon, J. Env. Chem. Eng. 2013, 1:786-794. DOI:10.1016/j.jece.2013.07.020.

[24] T. Panswad, C. Anan, Bioresource Technol. 1999, 70:237-243. DOI: 10.1016/S0960-8524 (99) 00041-3.

[25] B.M. Wilén, B. Jin, P. Lant, Water Res. 2003, 37:2127-2139. DOI: 10.1016/S0043-1354(02)006292.

[26] C.H Lee, J.C Liu, Water Res. 2000, 34:4430-4436. DOI: 10.1016/S0043-1354(00)00209-8.

[27] P. Jarvis, B. Jefferson, J. Gregory, S.A. Parsons, Water Res. 2005, 39:3121-3137. DOI: 10.1016/j.watres.2005.05.022.

[28 ] T.P. Nguyen, N. Hilal, N.P. Hankins, J.T. Novak, Desalination. 2007, 222:307-317. DOI:10.1016/j.desal.2007.01.161 


\section{Tables}

Table 1. Composition of the diluted wastewater samples

\begin{tabular}{ll}
\hline Parameter & Values \\
\hline $\mathrm{pH}$ & $6.3-8.40$ \\
Conductivity $\left(\mathrm{mS} \mathrm{cm}^{-1}\right)$ & $7.4-8.75$ \\
Turbidity (NTU) & $75-170$ \\
Phosphorous (mg L & -1 ) \\
Suspended solids, SS, $\left(\mathrm{mg} \mathrm{L}^{-1}\right)$ & $3.20-3.50$ \\
Soluble COD $\left(\mathrm{mg} \mathrm{L}^{-1}\right)$ & $1500-4050$ \\
$\mathrm{BOD}_{5}\left(\mathrm{mg} \mathrm{L}^{-1}\right)$ & $480-1225$ \\
\hline
\end{tabular}

Table 2. SBR operating parameters

\begin{tabular}{|c|c|c|c|c|}
\hline \multirow[b]{2}{*}{ Operation parameter } & \multicolumn{4}{|c|}{ HRT } \\
\hline & $144 \mathrm{~h}$ (T1) & $\begin{array}{l}71 \mathrm{~h} \\
(\mathrm{~T} 2)\end{array}$ & $\begin{array}{l}57.6 \mathrm{~h} \\
(\mathrm{~T} 3)^{*}\end{array}$ & $\begin{array}{l}48 \mathrm{~h} \\
(\mathrm{~T} 4)^{*}\end{array}$ \\
\hline$t_{C}\left(\right.$ h cycle $\left.^{-1}\right)$, & 12 & 12 & 12 & 12 \\
\hline$t_{F}(\min )$ & 7 & 14 & 17 & 20 \\
\hline$t_{R}(\min )$ & 540 & 540 & 540 & 540 \\
\hline $\mathrm{ts}_{\mathrm{s}}(\mathrm{min})$ & 100 & 100 & 100 & 100 \\
\hline$t_{D}(\min )$ & 3 & 6 & 7 & 8 \\
\hline$t_{1}(\min )$ & 70 & 63 & 60 & 57 \\
\hline$V_{\text {reaction }}(\mathrm{L})$ & 6 & 6 & 6 & 6 \\
\hline FTR & 0.010 & 0.019 & 0.024 & 0.028 \\
\hline VER & 0.083 & 0.167 & 0.208 & 0.250 \\
\hline $\begin{array}{l}\text { Replacement volume per } \\
\text { cycle }\left(\mathrm{L} \mathrm{cycle}^{-1}\right), V_{F}\end{array}$ & 0.50 & 1.00 & 1.25 & 1.50 \\
\hline
\end{tabular}

* Tests 3 and 4 (the best results) were duplicated in order to see the reproducibility of measurements.

Table 3. Properties of the tested polyelectrolytes provided by the manufacturer.

\begin{tabular}{lcc}
\hline Parameter & Chemifloc CH-30 & Chemifloc CV-250 \\
\hline Density $\left(\mathrm{g} \mathrm{mL}^{-1}\right.$ ) & 0.85 & 0.80 \\
Viscosity at $0.25 \%(\mathrm{cps})$ & 400 & 400 \\
Charge type & cationic & cationic \\
Molecular weight $\left(\mathrm{g} \mathrm{mol}^{-1}\right)$ & $5.0 \cdot 10^{6}-8.0 \cdot 10^{6}$ & $8.0 \cdot 10^{6}-1.1 \cdot 10^{7}$ \\
$\mathrm{pH}\left(5 \mathrm{~g} \mathrm{~L}^{-1}\right)$ & $2.5-4.5$ & $2.5-4.5$ \\
Particle Distribution Size & $2 \%>10$ mesh & $2 \%>10$ mesh \\
& $6 \%<100$ mesh & $6 \%<100$ mesh \\
\hline
\end{tabular}




\section{Figures}

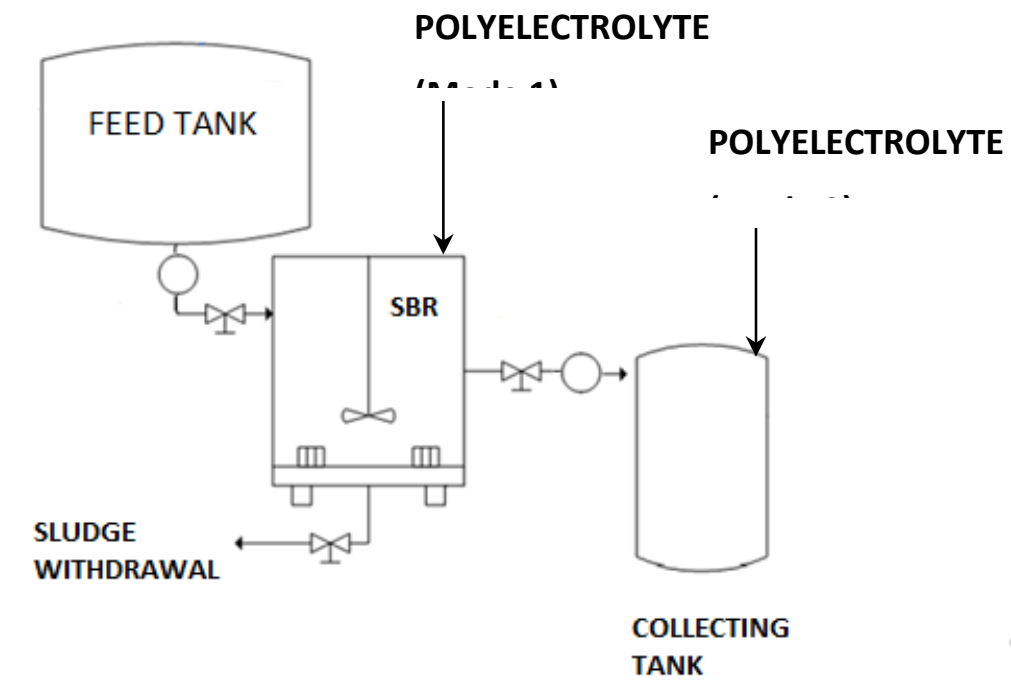

Figure 1. SBR laboratory plant scheme.

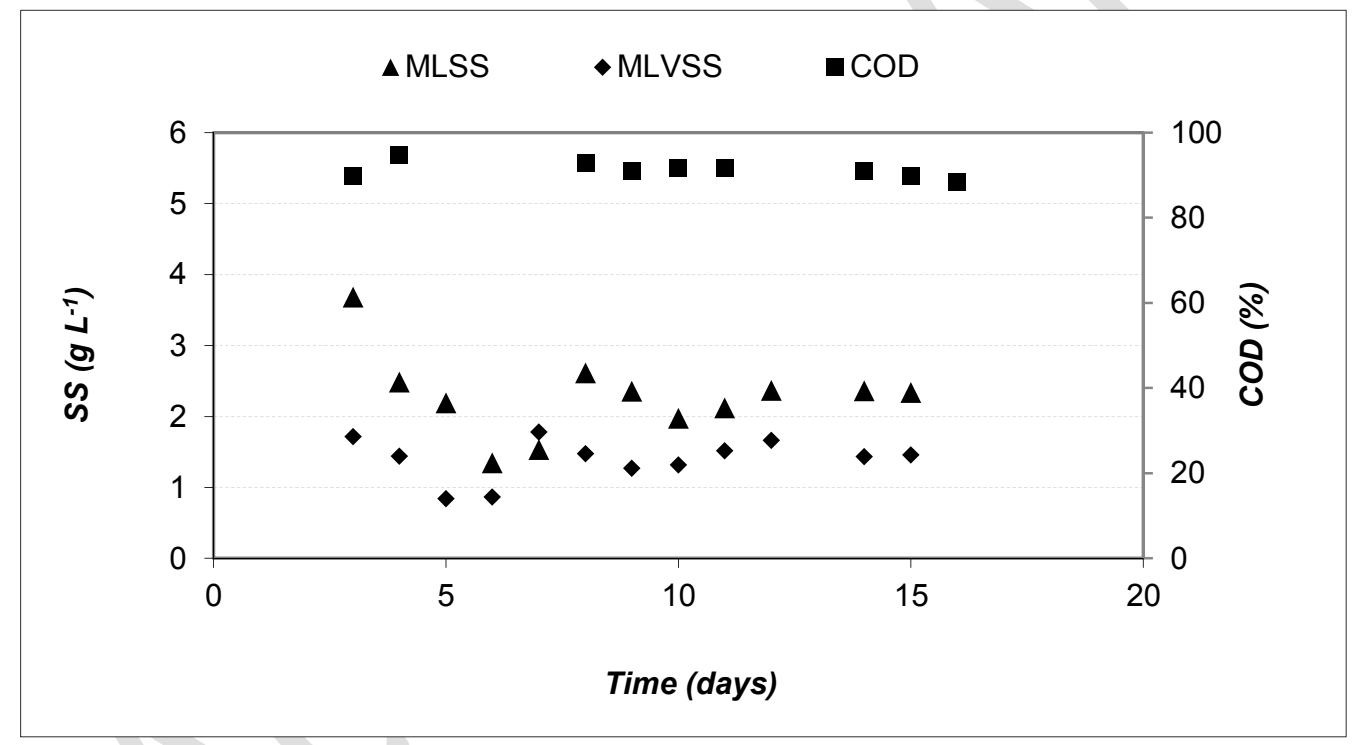

Figure 2. Evolution of the MLSS, MLVSS and soluble COD in the acclimatization stage. 

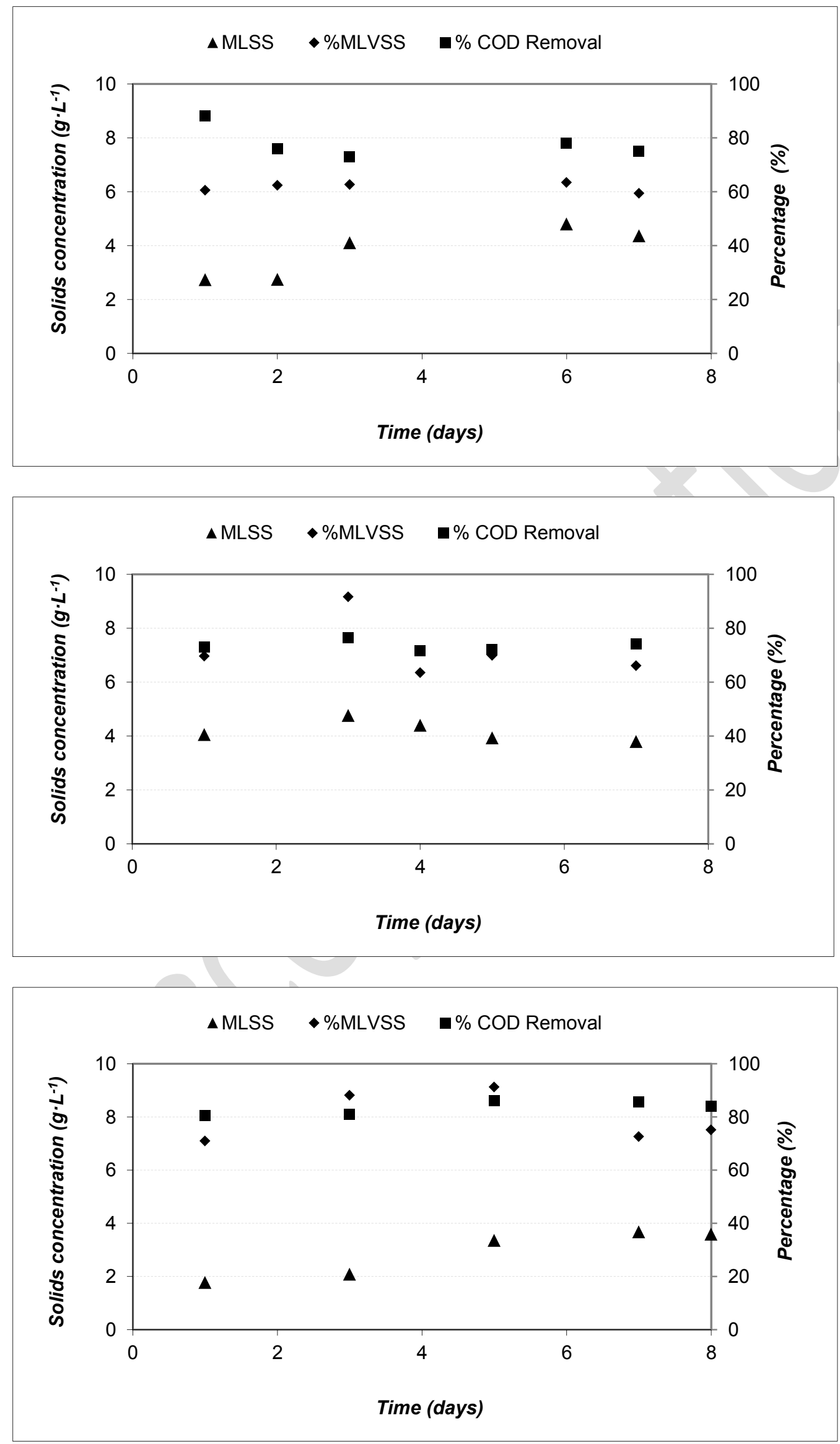

This article is protected by copyright. All rights reserved. 


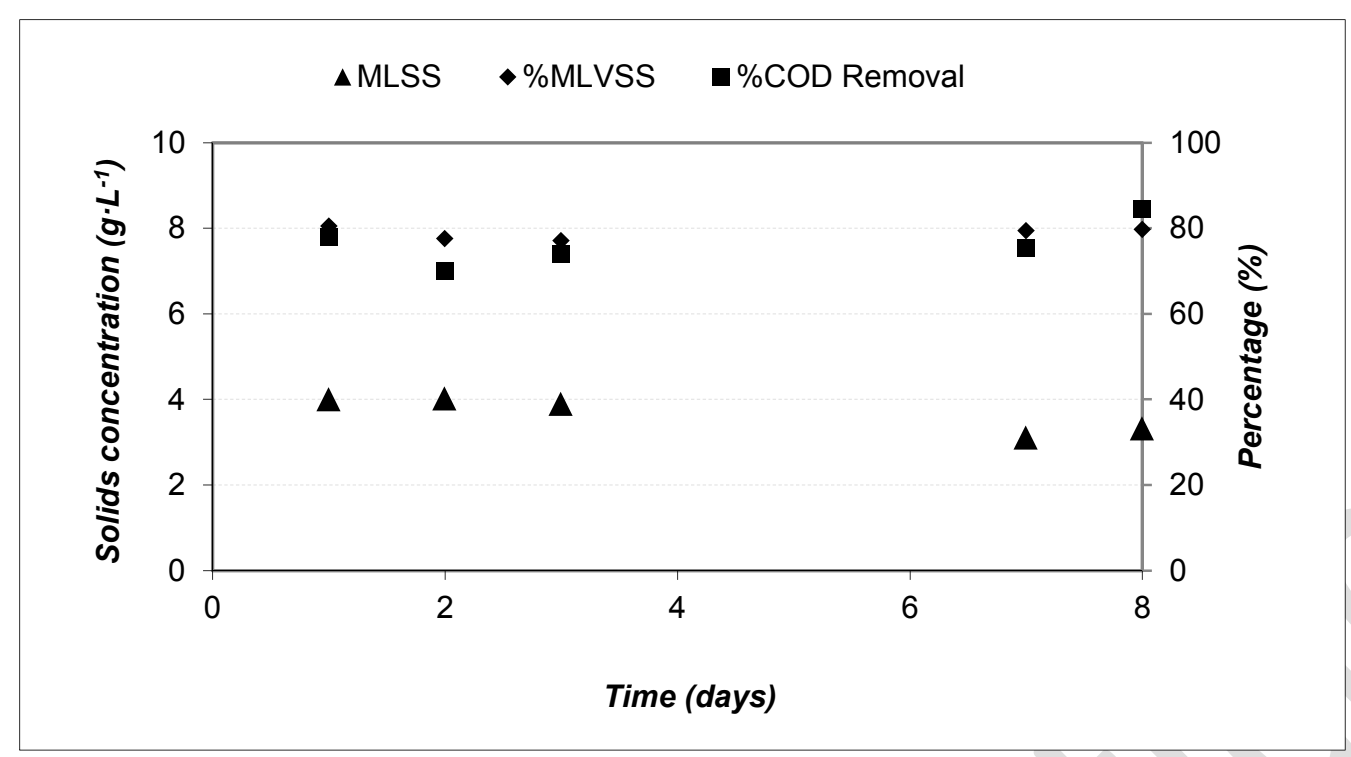

Figure 3. Evolution of MLSS, MLVSS and soluble COD for each HRT: (a) HRT=144 $h$, (b) $H R T=71 \mathrm{~h}$, (c) HRT=57.6 h, (d) HRT=48 h. 

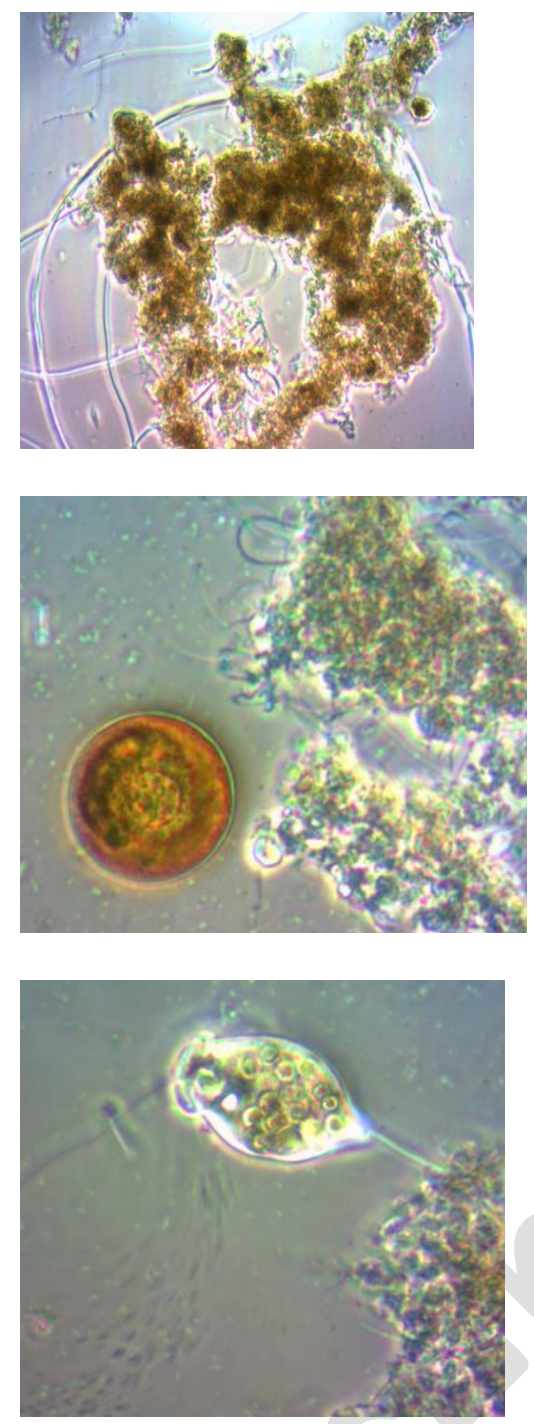

Figure 4. Microscopic images of the mixed liquor (x400) (from test T4): (a) Filamentous bacteria, (b) Ameboid, (c) Vorticella. 


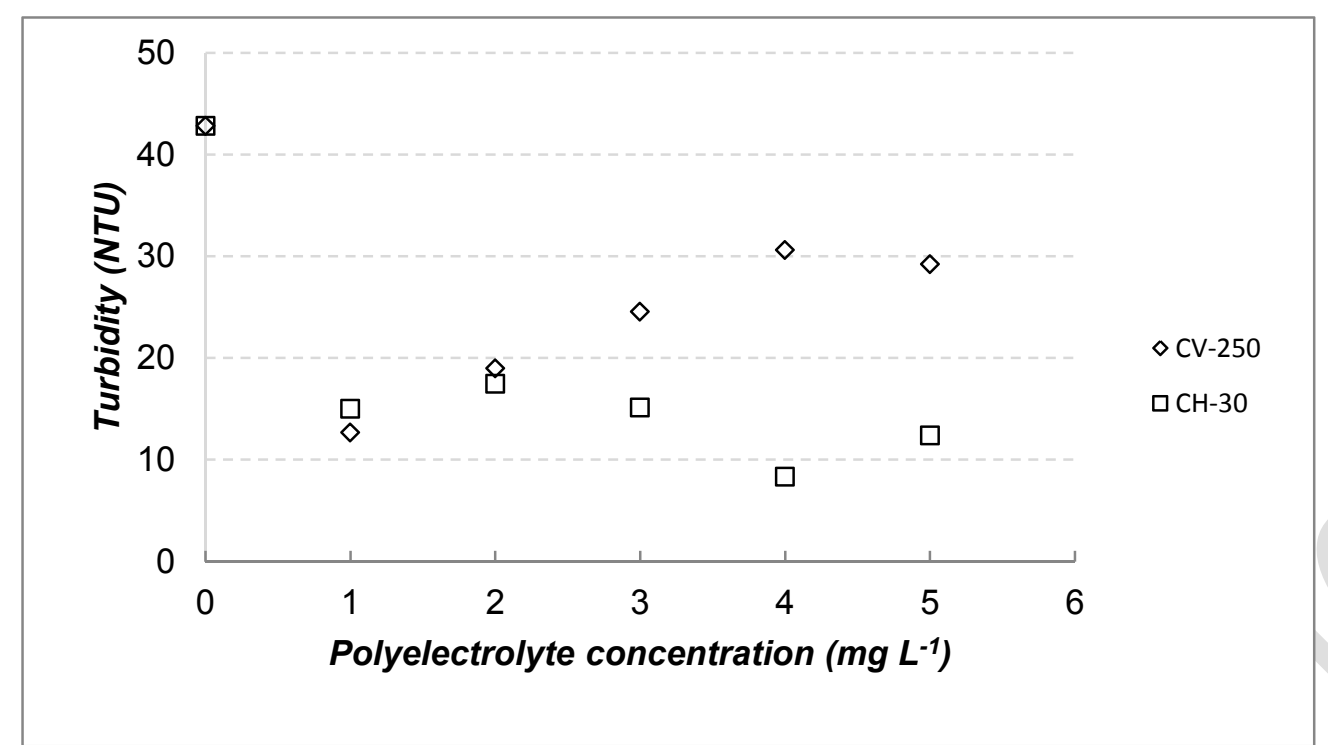

Figure 5. Influence of $\mathrm{CV}-250$ and $\mathrm{CH}-30$ concentrations on the turbidity of the effluent.

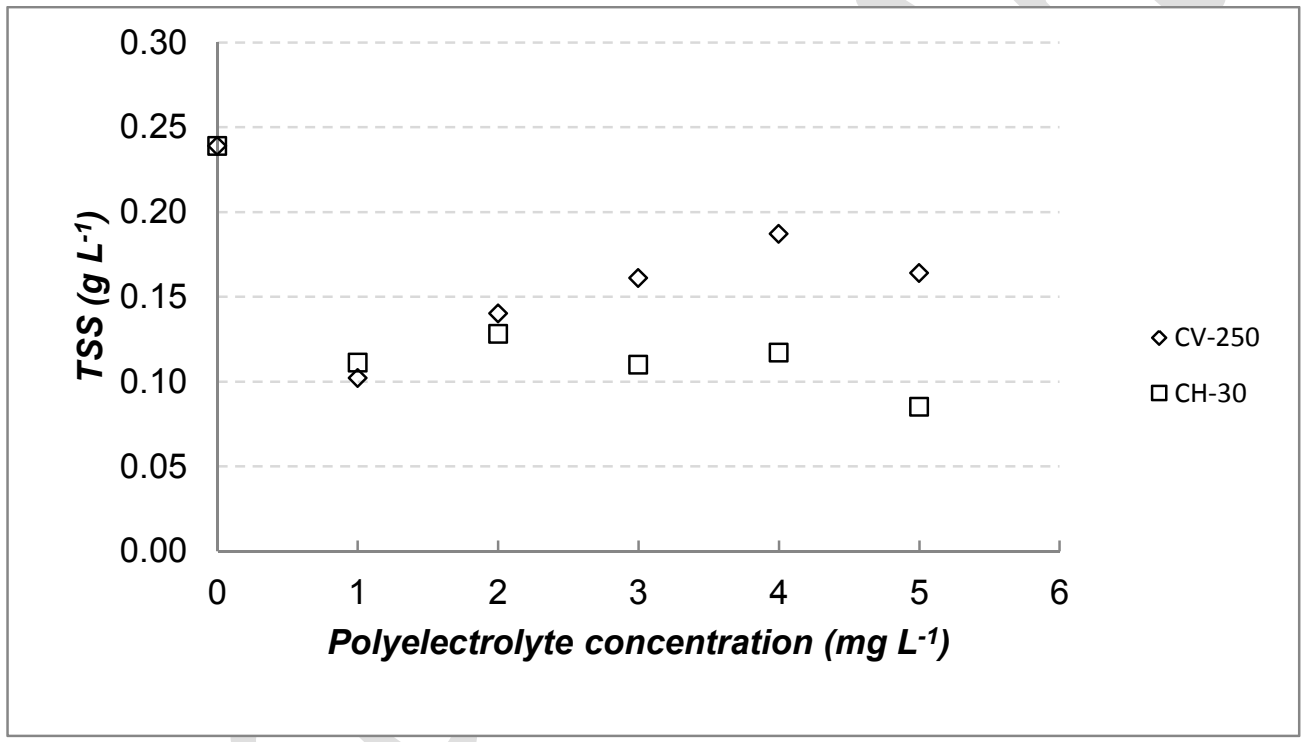

Figure 6. Influence of $\mathrm{CV}-250$ and $\mathrm{CH}-30$ concentrations on total suspended solids of the effluent. 


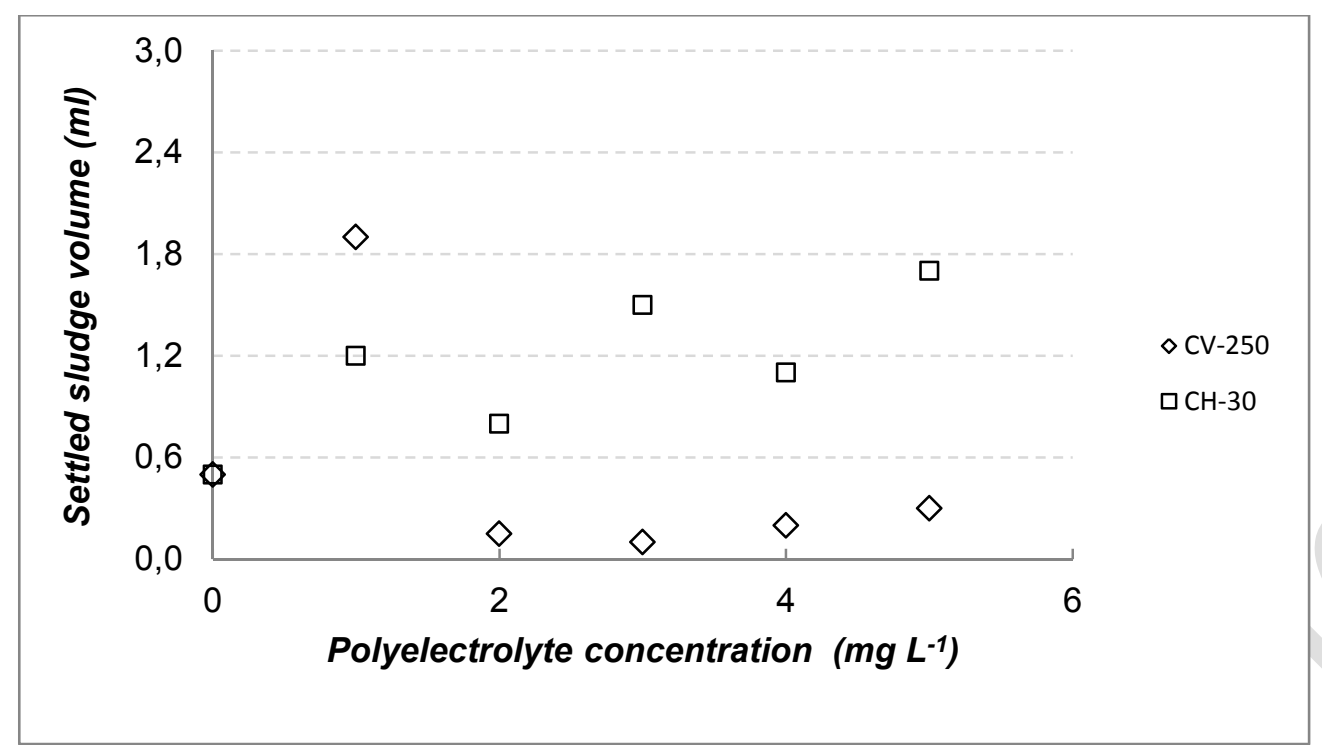

Figure 7. Influence of CV-250 and $\mathrm{CH}-30$ concentrations on settled sludge volume $\left(\mathrm{V}_{30}\right)$ 

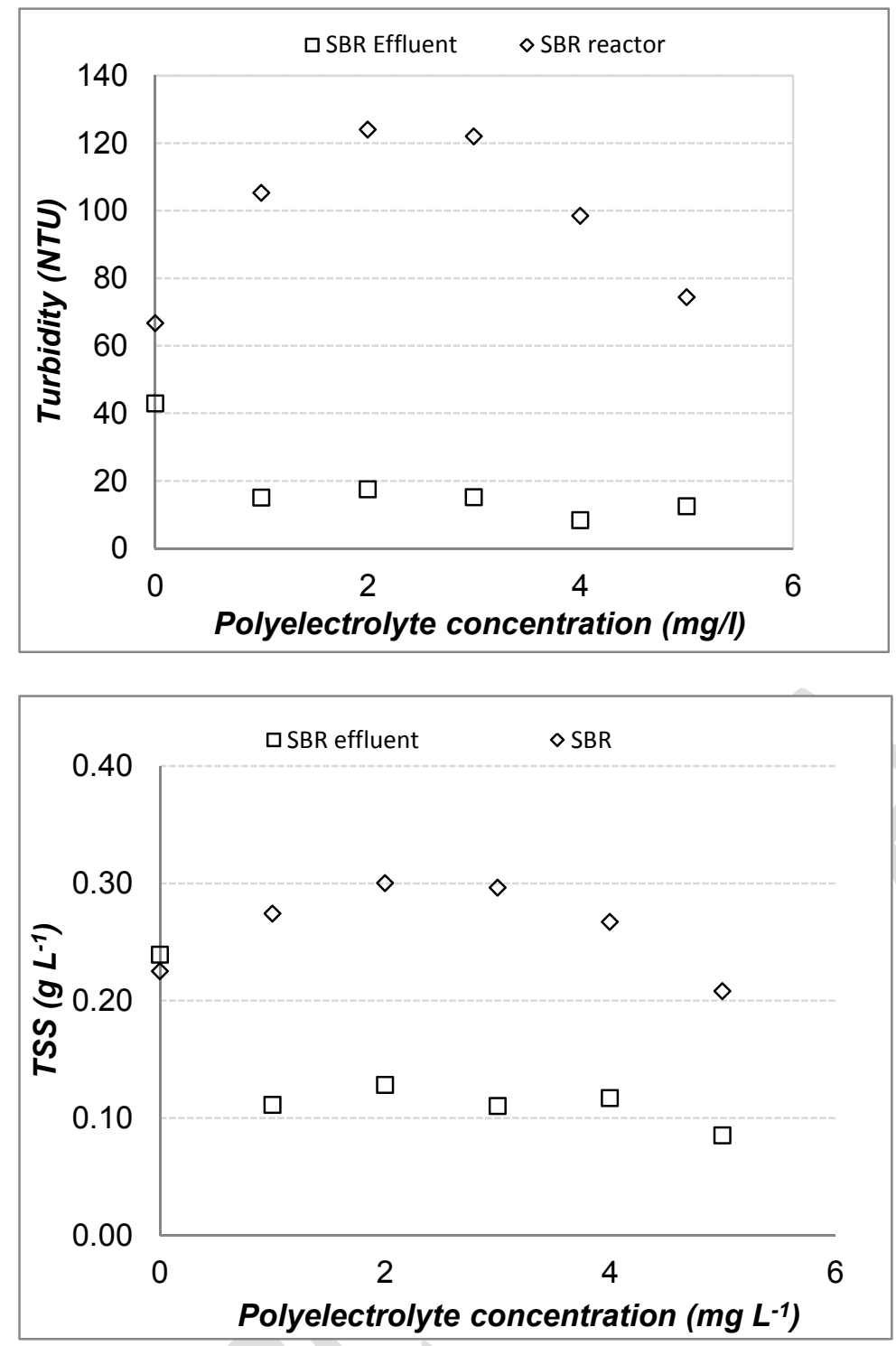

Figure 8. Results for the effluent using CH-30 Polyelectrolyte: (a) Turbidity and (b) TSS. 